\title{
Ukuran Kantor Akuntan Publik, Ukuran Perusahaan, Pergantian Manajemen dan Pergantian Kantor Akuntan Publik
}

\author{
Putu Agoes Suanthara ${ }^{1}$ \\ Fakultas Ekonomi dan Bisnis \\ Universitas Udayana, Indonesia
}

\author{
I Gde Ary Wirajaya ${ }^{2}$ \\ Fakultas Ekonomi dan Bisnis \\ Universitas Udayana, Indonesia
}

Surel : agoessuanthara18@gmail.com

\section{ABSTRAK}

Tujuan penelitian ini adalah untuk mengetahui pengaruh ukuran Kantor Akuntan Publik (KAP), ukuran perusahaan, dan pergantian manajemen pada pergantian KAP. Penelitian ini dilakukan pada perusahaan sektor infrastruktur, utilitas, dan transportasi yang terdaftar di BEI tahun 2014-2018. Metode penentuan sampel yang digunakan adalah teknik purposive sampling sehingga didapatkan 11 perusahaan dengan total amatan sebanyak 55 sampel selama 5 tahun. Pengumpulan data dilakukan dengan mengakses situs resmi BEI. Teknik analisis yang digunakan adalah regresi logistik. Berdasarkan hasil penelitian ini diketahui bahwa ukuran KAP berpengaruh negatif pada pergantian KAP. Variabel ukuran perusahaan dan pergantian manajemen tidak berpengaruh pada pergantian KAP.

Kata Kunci: Ukuran KAP; Ukuran Perusahaan; Pergantian Manajemen; Pergantian KAP.

\section{Size of the Public Accounting Firm, Size of the Company, Change of Management and Change of Public Accounting Firm}

\begin{abstract}
The purpose of this study was to determine the effect of the size of the Public Accounting Firm (KAP), the size of the company, and the change of management on KAP Substitution. Research conducted on infrastructure, utilities and transportation companies listed on the Indonesia Stock Exchange in 2014-2018. The sampling method used is purposive sampling technique and the number of samples chosen is 11 companies with 55 samples in 5 years. Data collected by accessing the IDX official website to get the sample company's annual report, analyzed using logistic regression. Based on the results, KAP size has a significant negative effect on the KAP turnover. Company size and management change variables have a positive and not significant effect on public accounting firm changes.
\end{abstract}

Keywords: $\quad$ KAP Size; Company Size; Management Change; KAP Substitution.

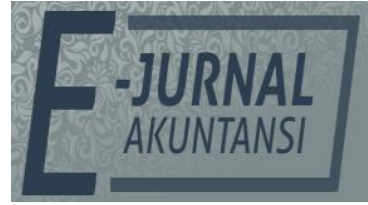

e-ISSN 2302-8556

Vol. 31 No. 4

Denpasar, April 2021

Hal. 894-908

DOI:

10.24843/EJA.2021.v31.i04.p08

PENGUTIPAN:

Suanthara, P. A., \& Wirajaya, I G.A. (2021). Ukuran Kantor Akuntan Publik, Ukuran

Perusahaan, Pergantian

Manajemen dan Pergantian Kantor Akuntan Publik. E-Jurnal Akuntansi, 31(4), 894-908

RIWAYAT ARTIKEL: Artikel Masuk: 9 Juli 2020

Artikel Diterima: 19 Februari 2021

Artikel dapat diakses : https://ojs.unud.ac.id/index.php/Akuntansi/index 


\section{PENDAHULUAN}

Arus transaksi pasar modal yang semakin meningkat dewasa ini salah satunya disebabkan oleh makin banyaknya jumlah perusahaan yang go public. Hal ini mendorong para investor berlomba-lomba untuk menanamkan modalnya di Indonesia. Investor tentunya akan memerlukan laporan keuangan perusahaan sebagai bahan pertimbangan atau digunakan untuk memantau kinerja suatu perusahaan. Laporan keuangan yang disajikan oleh suatu perusahaan menyediakan berbagai informasi yang nantinya diperlukan sebagai sarana untuk pengambilan keputusan baik pihak internal maupun eksternal (Aprillia, 2013).

Perusahaan go public akan menerbitkan laporan keuangan yang relevan serta andal untuk menarik minat investor dan sebagai alat pertanggungjawaban bagi para pemegang saham. Pihak ketiga independen sangat berperan penting untuk menghasilkan laporan keuangan yang relevan dan andal. Akuntan publik merupakan pihak ketiga independen yang dipercaya mampu untuk memberikan jaminan atas keandalan suatu laporan keuangan. Hal ini disebabkan karena akuntan publik dapat mendeteksi dan mencegah conflict of interest yang dapat terjadi antara pemegang saham dan manajemen perusahaan. Tugas akuntan publik secara umum adalah memeriksa dan memberikan opini atas kewajaran penyajian laporan keuangan perusahaan. Opini yang diberikan oleh akuntan publik dapat memberikan keyakinan bahwa laporan keuangan tidak mengandung salah saji (misstatement) ataupun penghilangan (omission) yang material (Aprillia, 2013).

Independensi merupakan sikap yang harus dimiliki akuntan publik dalam. proses pelaksanaan audit. Independensi dapat diartikan sebagai kebebasan dalam hubungan (freedom from relationship) yang dapat merusak objektivitas akuntan publik. IESBA Code of Ethics for Professional Conduc. yang dikutip Arens et al., (2012) menyatakan bahwa seorang akuntan publik harus independen dalam fakta (independence in fact) dan independen dalam penampilan (independence in appearance). Independen dalam fakta artinya seorang akuntan publik dapat mempertahankan sikap yang tidak bias sepanjang pelaksanaan audit, sedangkan independen dalam penampilan merupakan hasil interpretasi dari pihak lain terhadap independensi akuntan publik. Menurut Mintz (2018), profesi akuntan publik dilarang memiliki hubungan pribadi dengan klien untuk menjaga kepercayaan publik dalam fungsi audit dan untuk melindungi objektivitas.

Salah satu cara meningkatkan independensi akuntan publik adalah dengan melakukan pembatasan perikatan audit antara akuntan publik atau KAP dengan klien melalui pergantian KAP. Hal ini dimaksudkan untuk mencegah terjalinnya kerjasama yang lama dan berakibat pada hilangnya independensi akuntan publik. Skandal Perusahaan Enron dan KAP Arthur Anderson menjadi bukti pentingnya pembatasan waktu perikatan audit. Enron merupakan perusahaan energi yang hanya dalam waktu 15 tahun, sukses menjadi perusahaan terbesar ketujuh di Amerika Serikat dan merupakan klien dari KAP Arthur Anderson yang masuk dalam jajaran The Big Five. Diketahui dalam kasus Enron, KAP Arthur Anderson tidak dapat mempertahankan independensinya sehingga manajemen dapat memanipulasi laporan keuangan perusahaan. Skandal tersebut menyebabkan turunnya kepercayaan publik terhadap kualitas audit. The Sarbanes 
Oxley Act (SOX) pada tahun 2002 akhinya memunculkan regulasi yang mengatur tentang batasan-batasan yang dijadikan pedoman dalam memberikan jasa audit. Salah satu batasan yang termuat dalam regulasi tersebut adalah pembatasan perikatan kerja antara akuntan publik dan klien (auditor switching).

Beberapa negara kemudian membuat regulasi yang mengatur tentang masa perikatan audit untuk meningkatkan independensi akuntan publik (Corbella et al. 2012). Indonesia merupakan salah satu negara yang memiliki regulasi tentang masa perikatan audit antara akuntan publik dengan klien. Berdasarkan PP No. 20/2015, perusahaan tidak lagi diwajibkan untuk melakukan pergantian KAP dalam kurun waktu tertentu. Walaupun perusahaan tidak lagi dibatasi melakukan perikatan dengan KAP yang sama, masih terdapat beberapa kasus perusahaan yang melakukan pergantian KAP. Fenomena pergantian KAP pada perusahaan yang terdaftar di Bursa Efek Indonesia dalam tiga tahun terakhir dapat dilihat pada tabel 1.

Tabel 1. Fenomena Pergantian KAP yang Terdaftar di BEI Periode 2016-2018

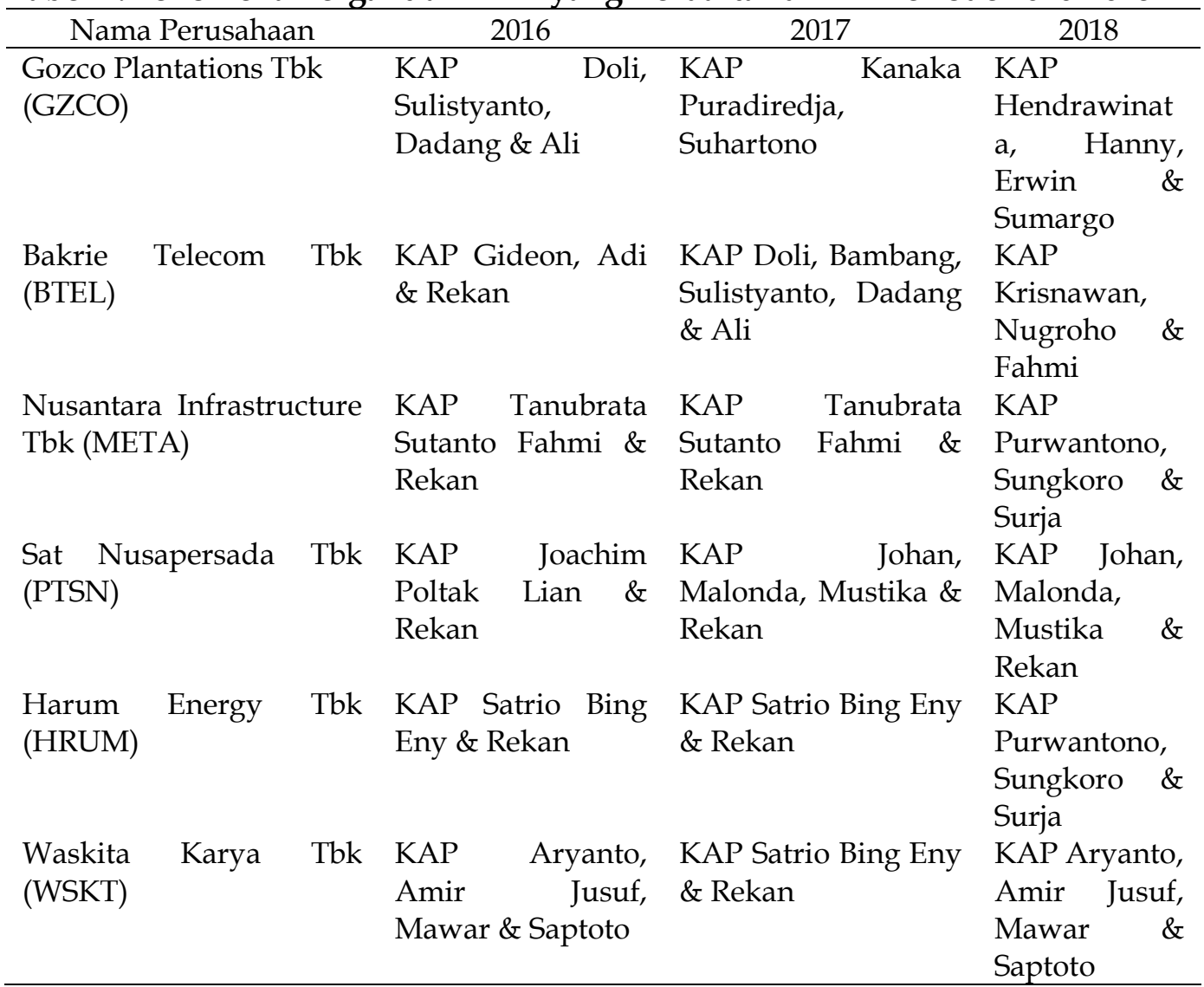

Sumber: www.idx.co.id, 2019

Fenomena pergantian KAP pada beberapa perusahaan yang terdapat di Bursa Efek Indonesia (BEI) masih terjadi meskipun perusahaan tidak lagi diwajibkan untuk mengganti KAP dalam kurun waktu tertentu. Menurut Chadegani et al. (2011) terdapat dua faktor penyebab terjadinya pergantian KAP, yaitu: 1) Faktor dari akuntan publik: fee audit, opini audit, kualitas audit serta 2) Faktor dari klien: ukuran perusahaan klien, pergantian manajemen, kesulitan keuangan. Penelitian ini menggunakan ukuran KAP, ukuran perusahaan, dan 
pergantian manajemen untuk diteliti pengaruhnya pada pergantian KAP. Pemilihan tiga variabel independen ini didasarkan pada perbedaan hasil penelitian terdahulu dari variabel tersebut.

Ukuran Kantor Akuntan Publik yang kemudian disingkat menjadi ukuran KAP merupakan salah satu faktor yang diduga menjadi penyebab perusahaan melakukan pergantian KAP. Ukuran KAP merupakan besar kecilnya suatu KAP yang digunakan perusahaan (Kasharmeh, 2015). KAP besar mampu mengaudit laporan keuangan perusahaan lebih cepat dan efisien dibandingkan dengan KAP kecil (Indah Sari \& Widanaputra, 2016). Beberapa kelebihan-kelebihan dari KAP besar tersebut kemungkinan akan dipertimbangkan perusahaan dalam menentukan apakah akan melakukan pergantian KAP atau tidak. Penelitian yang dilakukan oleh Kasharmeh (2015), dan Budi et al. (2015) menunjukkan bahwa ukuran KAP berpengaruh pada pergantian KAP. Namun hasil penelitian yang dilakukan Meilala \& Sulistyawati (2017), serta Aroh et al. (2018) menunjukkan hasil yang bertolak belakang, yaitu ukuran KAP tidak berpengaruh pada pergantian KAP.

Ukuran perusahaan merupakan ukuran besar kecilnya perusahaan yang dapat diukur dengan total aset, nilai penjualan, dan kapitalisasi pasar (Dang et al., 2018). Perusahaan dapat dikategorikan menjadi tiga kelompok berdasarkan total aset perusahaan, yaitu perusahaan besar, perusahaan menengah, dan perusahaan kecil. Peraturan Otoritas Jasa Keuangan Nomor 53/POJK.04/2017 (POJK Nomor 53/POJK.04/2017) menyatakan bahwa ukuran perusahaan yang melakukan penawaran umum di Bursa Efek Indonesia (emiten) dapat dibedakan menjadi tiga kategori yaitu emiten skala besar (large firm), emiten skala menengah (medium size), dan emiten skala kecil (small firm). Ukuran besar kecilnya perusahaan dapat menggambarkan aktivitas sebuah perusahaan. Perusahaan yang berukuran besar mempunyai struktur organisasi yang lebih kompleks dibandingkan dengan perusahaan berukuran kecil. Hal ini menyebabkan hubungan agensi antara manajemen dengan pemilik akan semakin meningkat. Hubungan agensi yang semakin meningkat memungkinkan terjadinya conflict of interest antara pemegang saham dengan manajemen. KAP berperan untuk mencegah terjadinya conflit of interest antara pemegang saham dengan manajemen.

Sebuah ketidaksesuaian ukuran antara perusahaan klien yang besar diaudit oleh perusahaan audit yang kecil dapat menyebabkan berakhirnya keterlibatan audit. Pernyataan tersebut mengindikasikan bahwa perusahaan besar cenderung akan menggunakan jasa KAP besar pula untuk mengaudit laporan keuangan perusahaan. Penelitian yang dilakukan oleh Suparlan \& Andayani (2010) berhasil membuktikan adanya pengaruh ukuran perusahaan pada pergantian KAP. Namun, penelitian yang dilakukan oleh Sidhi \& Wirakusuma (2015), serta Suarjana \& Widhiyani (2015) mendapatkan hasil yang bertolak belakang, yaitu ukuran perusahaan tidak berpengaruh pada pergantian KAP.

Faktor selanjutnya yang diduga berpengaruh pada pergantian KAP adalah pergantian manajemen. Pergantian manajemen terjadi apabila perusahaan mengganti jajaran dewan direksinya. KAP akan dituntut untuk dapat beradaptasi dengan manajemen baru yang mungkin memiliki kebijakan akuntansi yang berbeda dibanding sebelumnya. Hasil penelitian yang dilakukan 
oleh Chadegani et al., (2011) berhasil membuktikan adanya pengaruh pergantian manajemen pada pergantian KAP. Sementara itu, penelitian yang dilakukan oleh Maryani \& Fahruriza (2015) gagal membuktikan adanya pengaruh pergantian manajemen pada pergantian KAP.

Tabel 2. Perkembangan Perdagangan Saham Sektoral Tahun 2018

\begin{tabular}{lcr}
\hline \multirow{2}{*}{ Sektoral } & \multicolumn{2}{c}{ Kapitalisasi Pasar } \\
\cline { 2 - 3 } & Nilai (Rp) & $\%$ \\
\hline Keuangan & 2.180 .757 .133 .296 .870 & 31.05 \\
Industri Konsumsi & 1.445 .771 .373 .306 .180 & 20.73 \\
Infra. Utilitas dan Transport & 734.432 .010 .216 .624 & 10.46 \\
Perdagangan & 680.229 .009 .977 .362 & 9.69 \\
Industri Dasar & 666.874 .464 .625 .249 & 9.49 \\
Aneka Industri & 413.190 .400 .697 .665 & 5.88 \\
Pertambangan & 401.132 .539 .691 .699 & 5.71 \\
Properti dan Real Estate & 390.519 .235 .472 .897 & 5.56 \\
Pertanian & 100.590 .602 .106 .028 & 1.43 \\
\hline
\end{tabular}

Sumber: https://ojk.go.id, 2019

Penelitian ini dilakukan pada perusahan sektor infrastruktur, utilitas, dan transportasi yang terdaftar di Bursa Efek Indonesia (BEI) tahun 2014-2018 karena penelitian mengenai topik pergantian KAP pada sektor ini relatif masih jarang ditemukan. Selain itu, menurut data perkembangan perdagangan saham sektoral tahun 2018 yang terdapat di website Otoritas Jasa Keuangan (OJK), sektor infrastruktur, utilitas dan transportasi masuk dalam tiga besar sektor dengan kapitalisasi pasar tertinggi pada tahun 2018. Berikut Tabel 2 yang menyajikan Perkembangan Perdagangan Saham Sektoral Tahun 2018 yang didapat dari website Otoritas Jasa Keuangan (OJK).

Perkembangan pembiayaan infrastruktur, utilitas, dan transportasi di pasar modal dinilai menunjukkan pertumbuhan signifikan. Berdasarkan total seluruh perusahaan yang terdaftar di BEI yang berjumlah 653 perusahaan, 75 perusahaan diantaranya masuk dalam sektor infrastruktur, utilitas, dan transportasi dengan kapitalisasi pasar senilai Rp 734 triliun dan kontribusi terhadap total kapitalisasi pasar sebesar 10,46 persen. Kapitalisasi pasar yang tinggi menandakan semakin tingginya nilai suatu perusahaan. Biasanya investor cenderung akan menanamkan modalnya pada perusahaan dengan kapitalisasi pasar yang tinggi untuk menghindari risiko investasi.

Penelitian ini mempunyai tujuan untuk mengetahui dan membuktikan secara empiris pengaruh ukuran KAP pada pergantian KAP, untuk mengetahui dan membuktikan secara empiris pengaruh ukuran perusahaan pada pergantian KAP dan untuk mengetahui dan membuktikan secara empiris pengaruh pergantian manajemen pada pergantian KAP.

Theory of Planned Behaviour menjelaskan bahwa seseorang akan memikirkan implikasi dari suatu tindakan sebelum memutuskan untuk melakukan atau tidak melakukan perilaku-perilaku tertentu (Ajzen, 1991). Beberapa keunggulan dari KAP berskala besar tersebut dipercaya dapat menurunkan risiko konflik kepentingan antara pemegang saham dan manajemen sehingga kepercayaan investor pada kinerja suatu perusahaan terjaga dan tetap memeroleh dana. Berdasarkan alasan tersebut, perusahaan cenderung akan memilih untuk tetap 
menggunakan KAP besar untuk menjaga kepercayaan investor. Salah satu komponen pembentuk Theory of Planned Behaviour adalah attitude towards behavior yang merupakan tingkat dimana seseorang mengevaluasi atau menilai perilaku secara positif maupun negatif. Keyakinan akan hasil positif yang didapatkan perusahaan ketika menggunakan jasa KAP besar menyebabkan perusahaan yang telah bekerja sama dengan KAP besar cenderung untuk tidak mengganti KAP. Penelitian yang dilakukan oleh Kasharmeh (2015), Satriantini, et al. (2014), dan Aprillia (2013) berhasil membuktikan bahwa ukuran KAP berpengaruh negatif pada pergantian KAP. Berdasarkan kajian teoritis dan kajian empiris, maka hipotesis pertama.

$\mathrm{H}_{1}$ : Ukuran KAP berpengaruh. negatif pada.pergantian KAP.

Perusahaan yang tumbuh menjadi perusahaan yang besar akan menyebabkan peningkatan pemisahan antara manajemen dan kepemilikan. Keadaan ini dapat menyebabkan timbulnya perbedaan kepentingan karena semakin sulitnya pemilik untuk memantau dan melakukan pengendalian atas perilaku manajer yang mungkin saja akan berperilaku untuk memaksimalkan keuntungan pribadinya dibandingkan dengan keuntungan pemilik. Keadaan tersebut dapat diatasi dengan menggunakan KAP yang lebih besar untuk mengurangi risiko. KAP besar umumnya dianggap sebagai penyedia kualitas audit yang tinggi dan menikmati reputasi tinggi dalam lingkungan bisnis (Nasser, et al. 2006). Menurut Hudaib \& Cooke (2005), sebuah ketidaksesuaian ukuran antara perusahaan besar yang diaudit oleh perusahaan audit yang kecil akan menyebabkan berakhirnya keterlibatan audit. Terdapat indikasi antara perusahaan yang mengalami pertumbuhan semakin besar akan beralih pada KAP berskala besar pula (Weiner, 2012). Ukuran perusahaan yang semakin meningkat memungkinkan jumlah konflik agen juga semakin meningkat (Palmrose, 1986). Perusahaan besar yang melakukan pergantian ke KAP yang besar bertujuan untuk menurunkan risiko terjadinya konflik kepentingan dan menjaga kepercayaan pemilik pada perusahaan.

Menurut Theory of Planned Behaviour, intensi individu melakukan perilaku ditentukan oleh adanya sikap terhadap perilaku (attitude towards behavior) dan norma subyektif (subjective norms) (Ajzen, 1991). Perusahaan besar cenderung melakukan pergantian ke KAP yang lebih besar karena pergantian KAP dinilai akan membawa dampak positif bagi perusahaan dan adanya dorongan dari investor untuk menggunakan KAP yang lebih berkualitas. Penelitian yang dilakukan oleh Mahantara (2013) dan Suparlan \& Andayani (2010) berhasil membuktikan adanya pengaruh ukuran perusahaan pada pergantian KAP. Berdasarkan kajian teoritis dan kajian empiris, maka hipotesis kedua sebagai berkut.

$\mathrm{H}_{2}$ : Ukuran perusahaan berpengaruh positif pada pergantian KAP.

Pergantian manajemen terjadi apabila perusahaan mengganti jajaran dewan direksinya. Pergantian manajemen akan menimbulkan perubahan dalam kebijakan perusahaan. Manajemen akan berniat melakukan pergantian KAP apabila KAP tersebut tidak dapat beradaptasi dengan kebijakan baru perusahaan. Menurut Susanto (2018), manajemen baru cenderung akan mencari KAP yang selaras dengan kebijakan perusahaan dan pelaporan akuntansinya. Pergantian manajemen akan membuat manajemen baru memiliki kesempatan 
untuk mencari KAP baru yang lebih berkualitas, lebih dapat diajak bekerja sama, dan sejalan dengan kebijakan serta pelaporan akuntansinya. Keselarasan antara KAP dengan kebijakan perusahaan akan memberikan peluang bagi perusahaan untuk mendapatkan opini yang diharapkan pada laporan keuangan perusahaan. Opini tersebut nantinya akan digunakan oleh pemilik untuk memantau perilaku dari manajemen perusahaan. Theory of Planned Behaviour didasarkan pada asumsi bahwa manusia berperilaku dengan cara yang masuk akal dan memikirkan implikasi dari tindakan mereka sebelum melakukan suatu perilaku (Ajzen, 1991). Adanya pergantian KAP akan memberikan kesempatan bagi manajemen untuk mendapatkan KAP yang lebih berkualitas, lebih dapat diajak bekerja sama, dan sejalan dengan kebijakan serta pelaporan akuntansinya. Salah satu komponen pembentuk perilaku berdasarkan Theory of Planned Behaviour adalah sikap terhadap perilaku (attitude towards behavior), dimana manajemen baru menilai akan adanya dampak positif yang ditimbulkan apabila melakukan pergantian KAP karena manajemen baru akan memiliki kesempatan untuk melakukan perikatan dengan KAP yang sesuai dengan keinginan manajemen.

Penelitian ini memproksikan pergantian manajemen dengan pergantian direktur utama (Chief Excecutive Officer) karena direktur utama merupakan top management (manajemen puncak) yang bertanggung jawab terhadap informasi keuangan yang diterbitkan perusahaan. adanya pengaruh positif pergantian manajemen pada pergantian KAP yang didukung oleh penelitian yang dilakukan oleh Bagherpour et al. (2008) dan Kasharmeh (2015) yang juga berhasil membuktikan adanya pengaruh pergantian manajemen pada pergantian KAP. Berdasarkan kajian teoritis dan kajian empiris, maka hipotesis ketiga sebagai berikut.

$\mathrm{H}_{3}$ : Pergantian manajemen berpengaruh positif pada pergantian KAP.

\section{METODE PENELITIAN}

Penelitian ini menggunakan pendekatan kuantitatif yang berbentuk asosiatif. Penelitian ini dilakukan pada perusahaaan sektor infrastruktur, utilitas, dan transportasi yang terdaftar Bursa Efek Indonesia (BEI) dengan mengakses situs resmi BEI. Obyek penelitian yang digunakan dalam penelitian ini adalah laporan tahunan (annual report) dan financial statement perusahaan infrastuktur, utilitas, dan transportasi yang listing di Bursa Efek Indonesia (BEI) periode 2014-2018. Variabel yang digunakan dalam penelitian ini adalah ukuran KAP, ukuran perusahaan, pergantian manajemen, dan pergantian KAP. Sektor infrastuktur, utilitas, dan transportasi dipilih karena penelitian mengenai pergantian KAP pada sektor ini relatif jarang ditemukan. Selain itu, menurut data perkembangan perdagangan saham sektoral tahun 2018 yang terdapat di website Otoritas Jasa Keuangan (OJK), sektor infrastruktur, utilitas dan transportasi masuk dalam tiga besar sektor dengan kapitalisasi pasar tertinggi pada tahun 2018. Periode tahun yang digunakan adalah 5 tahun, hal ini bertujuan untuk menjaga validitas data sesungguhnya.

Variabel bebas dalam penelitian ini adalah ukuran $\operatorname{KAP}\left(\mathrm{X}_{1}\right)$, ukuran perusahaan $\left(X_{2}\right)$, dan pergantian manajemen $\left(X_{3}\right)$. Variabel terikat di dalam penelitian ini adalah pergantian KAP $(Y)$. Jenis data yang digunakan adalah data kualitatif yang dikuantifikasi dan data kuantitatif. Data kualitatif adalah jenis 
data berupa informasi atau penjelasan yang dinyatakan dalam huruf atau kata dan bukan dalam bentuk angka. Sementara itu, data kuantitatif adalah jenis data berupa informasi atau penjelasan yang dinyatakan dalam angka. Penelitian ini menggunakan data yang diperoleh dari laporan tahunan (annual report), financial statement, dan daftar perusahaan sektor infrastruktur, utilitas, dan transportasi tahun 2014 - 2018 yang terdaftar di Bursa Efek Indonesia (BEI). Sumber data yang digunakan adalah data sekunder. Data sekunder adalah data yang mengacu pada informasi yang telah ada. Sumber data sekunder adalah catatan atau dokumentasi perusahaan, publikasi pemerintah, analisis industri oleh media, situs web, internet, dan sebagainya. Penelitian ini menggunakan data sekunder yang diperoleh dari situs resmi BEI.

Metode pengumpulan data yang digunakan dalam penelitian ini adalah purposive sampling. Metode purposive sampling adalah metode penentuan sampel berdasarkan tujuan penelitian. Adapun kriteria-kriteria yang digunakan sebagai penentuan sampel dalam penelitian ini adalah: 1) Perusahaan sektor infrastuktur, utilitas, dan transportasi yang terdaftar berturut-turut di BEI selama periode 2014-2018; 2) Perusahaan tersebut melakukan pergantian Kantor Akuntan Publik minimal 1 (satu) kali selama periode penelitian; 3) Apabila perusahaan melakukan pergantian KAP pada tahun 2014-2015, dipastikan bahwa pergantian KAP tersebut dilakukan secara sukarela (voluntary).

Teknik analisis data yang digunakan dalam penelitian ini adalah analisis regresi logistik (logistic regression) karena variabel dependen menggunakan variabel dummy. Teknik analisis data yang digunakan dalam penelitian ini adalah analisis regresi logistik (logistic regression) karena variabel dependen menggunakan variabel dummy. Tahapan dalam pengujian dengan menggunakan uji regresi logistik dapat dijabarkan sebagai berikut: 1) Menilai kelayakan model regresi (uji Hosmer and Lemeshow's Goodness of Fit Test); 2) Menilai keseluruhan model (overall model fit); 3) Koefisien determinasi (nagelkerke $R$ square); 4) Uji multikolinieritas; 5) Matriks klasifikasi; 6) Model regresi logistik yang terbentuk, dimana didapatkan persamaan sebagai berikut:

$L n=\frac{P K A P}{(1-P K A P)}=a-\beta_{1} U K+\beta_{2} U P+\beta_{3} P M+\varepsilon$

Dimana $a=$ Konstanta, $P K A P=$ Probabilitas melakukan pergantian KAP menggunakan variabel dummy (kode 1 bagi perusahaan yang melakukan pergantian KAP dan 0 sebaliknya), $U K=$ Ukuran $\mathrm{KAP}, U P=$ Ukuran perusahaan, $P M=$ Pergantian manajemen, $\beta 1-\beta 3=$ Koefisien regresi, $\varepsilon=$ Residual error .

\section{HASIL DAN PEMBAHASAN}

Penelitian ini mengambil rentang waktu lima tahun yang dimulai dari tahun 2014 sampai 2018 untuk menjaga validitas data. Alasan melakukan penelitian yang dimulai dari tahun 2014 sampai 2018 karena pada tahun 2015, pemerintah mengeluarkan Peraturan Pemerintah No. 20 Tahun 2015 tentang Praktik Akuntan Publik yang mengatur pembatasan waktu perikatan audit. Berdasarkan Peraturan Pemerintah No. 20 Tahun 2015, perusahaan tidak lagi diwajibkan untuk melakukan pergantian KAP dalam kurun waktu tertentu. Pembatasan hanya berlaku bagi akuntan publik yaitu selama 5 tahun berturut-turut. Populasi dalam penelitian ini adalah seluruh perusahaan sektor infrastruktur, utilitas, dan 
transportasi. yang terdaftar di BEI tahun 2014-2018 yaitu sebanyak 75 perusahaan. Berdasarkan data sekunder yang diperoleh dan diseleksi sesuai dengan kriteria yang telah ditentukan, maka diperoleh sampel sebanyak 11 perusahaan dengan waktu pengamatan lima tahun.

Tabe13. Hasil Statistik Deskriptif

\begin{tabular}{lcrrrr}
\hline & $\mathrm{N}$ & \multicolumn{1}{c}{ Minimum } & \multicolumn{1}{c}{ Maximum } & \multicolumn{1}{c}{ Mean } & \multicolumn{1}{c}{ Std. Deviation } \\
\hline PKAP & 55 & 0,00 & 1,00 & 0,29 & 0,45 \\
UK & 55 & 0,00 & 1,00 & 0,63 & 0,48 \\
UP & 55 & 93106,00 & 114968615,00 & 15769722,24 & 29851732,24 \\
PM & 55 & 0,00 & 1,00 & 0,22 & 0,41 \\
Valid N & 55 & & & &
\end{tabular}

Sumber: Data Penelitian, 2019

Variabel pergantian KAP $(\mathrm{Y})$ memiliki nilai minimum sebesar 0 dan nilai maksimum sebesar 1. Nilai rata-rata pergantian KAP sebesar 0,29 menunjukkan bahwa perusahaan yang melakukan pergantian KAP dan tidak melakukan pergantian KAP memiliki jumlah yang beragam dan didominasi oleh perusahaan yang tidak melakukan pergantian KAP dengan nilai standar deviasi sebesar 0,45. Variabel ukuran $\operatorname{KAP}\left(\mathrm{X}_{1}\right)$ memiliki nilai minimum sebesar 0 dan nilai tmaksimum sebesar 1 . Nilai rata-rata variabel ukuran KAP sebesar 0,63 yang menunjukkan bahwa terdapat lebih banyak perusahaan yang menggunakan jasa akuntan tpublik dari KAP besar dengan nilai standar deviasi sebesar 0,48.

Variabel ukuran perusahaan $\left(\mathrm{X}_{2}\right)$ memiliki nilai minimum sebesar 93.106 (dalam jutaan) dan nilai maksimum sebesar 114.968 .615 (dalam jutaan). Nilai rata-rata variabel ukuran perusahaan adalah sebesar 15.769.722,24 (dalam jutaan) yang menunjukkan bahwa rata-rata perusahaan sampel didominasi oleh perusahaan besar. Standar deviasi dari variabel ukuran perusahaan adalah sebesar 29.851.732,24 (dalam jutaan). Variabel pergantian manajemen $\left(X_{3}\right)$ memiliki nilai minimum sebesar 0 dan nilai maksimum sebesar 1 . Nilai rata-rata sebesar 0,22 menunjukkan bahwa sampel didominasi oleh perusahaan yang tidak melakukan pergantian manajemen (CEO). Standar deviasi dari variabel ini adalah sebesar 0,41.

Tabe1 4. Perbandingan -2 Log Likelihood Awal dan Akhir

-2 Log Likelihood (-2LogL) pada awal

66,326

-2 Log Likelihood (-2LogL) pada akhir 58,375

Sumber: Data Penelitian, 2019

Nilai -2 LogL awal sebesar 66,326 dan nilai -2LogL akhir sebesar 58,375 menunjukkan bahwa terdapat penurunan nilai likelihood yang berarti model regresi baik atau fit dengan data.

Tabel 5. Model Summary

\begin{tabular}{cccc}
\hline Step & $\begin{array}{c}-2 \text { Log } \\
\text { Likelihood }\end{array}$ & $\begin{array}{c}\text { Cox E Snell } R \\
\text { Square }\end{array}$ & $\begin{array}{c}\text { Nagelkerke } R \\
\text { Square }\end{array}$ \\
\hline 1 & $58,375^{\text {a }}$ & 0,135 & 0,192 \\
\hline
\end{tabular}

Sumber: Data Penelitian, 2019

Nagelkerke $R$ Square sebesar 0,192. Hal ini berarti variabel independen yang digunakan dalam penelitian ini yaitu ukuran KAP, ukuran perusahaan, dan pergantian manajemen mempengaruhi variabel dependen yaitu pergantian KAP 
sebesar 19,2 persen sedangkan 80,8 persen dipengaruhi oleh variabel lain yang tidak dimasukkan dalam penelitian ini.

Tabel 6. Hasil Uji Multikolinieritas

\begin{tabular}{lrrrr}
\hline & Constant & $X_{1}$ & $X_{2}$ & $X_{3}$ \\
\hline Constant & 1,000 & 0,256 & $-0,204$ & $-0,169$ \\
$X_{1}$ & 0,256 & 1,000 & $-0,256$ & $-0,073$ \\
$X_{2}$ & $-0,204$ & $-0,256$ & 1,000 & $-0,021$ \\
$X_{3}$ & $-0,169$ & $-0,073$ & $-0,021$ & 1,000 \\
\hline
\end{tabular}

Sumber: Data Penelitian, 2019

Hasil uji multikolinieritas menunjukkan tidak ada nilai koefisien korelasi antara variabel independen yang nilainya lebih besar dari 0,9 maka dapat disimpulkan bahwa tidak terdapat gejala multikolinieritas yang serius antara variabel independen.

Tabel 7. Matriks Klasifikasi

\begin{tabular}{llllllr}
\hline & & \multicolumn{4}{c}{ Predicted } \\
\cline { 3 - 6 } & & & \multicolumn{3}{c}{ Pergantian KAP } & Percentage Correct \\
\cline { 3 - 6 } & & 0 & 37 & & 1 & 94,9 \\
\hline Step & Pergantian KAP & 0 & 10 & & 6 & 37,5 \\
1 & & 1 & & 10 & 78,2 \\
\hline
\end{tabular}

Sumber: Data Penelitian, 2019

Kekuatan prediksi dari model regresi untuk memprediksi kemungkinan perusahaan melakukan pergantian KAP (1) dan tidak melakukan pergantian KAP (0) sebesar 78,2 persen. Hal ini menunjukkan bahwa dengan menggunakan model regresi yang digunakan, terdapat sebanyak 6 perusahaan yang diprediksi akan melakukan pergantian KAP dari total 16 perusahaan yang melakukan pergantian KAP dengan persentase sebesar 37,5 persen. Kekuatan prediksi dari model regresi untuk memprediksi kemungkinan perusahaan tidak melakukan pergantian KAP sebesar 94,9 persen yang berarti bahwa dengan model regresi yang digunakan sebanyak 37 perusahaan diprediksi tidak melakukan pergantian KAP dari total 39 perusahaan yang tidak melakukan pergantian KAP.

Berdasarkan hasil analisis dengan menggunakan program SPSS 25 maka diperoleh hasil seperti yang dapat dilihat pada Tabel 8 .

Tabel 8.Variables in the Equation

\begin{tabular}{cccccccr}
\hline & & B & SE & Wald & Df & Sig & $\operatorname{Exp}(\mathrm{B})$ \\
\hline Step & $\mathrm{X}_{1}$ & $-0,810$ & 0,356 & 5,183 & 1 & 0,023 & 0,445 \\
$1^{\mathrm{a}}$ & $\mathrm{X}_{2}$ & 0,596 & 0,416 & 2,058 & 1 & 0,151 & 1,815 \\
& $\mathrm{X}_{3}$ & 0,362 & 0,368 & 0,969 & 1 & 0,325 & 1,437 \\
& Constant & $-1,049$ & 0,340 & 9,508 & 1 & 0,002 & 0,350 \\
\hline
\end{tabular}

Sumber: Data Penelitian, 2019

Berdasarkan Tabel 8 diperoleh persamaan regresi sebagai berikut.

$$
L n=\frac{P K A P}{(1-P K A P)}=-1,049-0,810 U K+0,596 U P+0,362 P M+\varepsilon
$$

Berdasarkan persamaan tersebut konstanta memiliki nilai sebesar $-1,049$. Angka tersebut mempunyai arti bahwa jika variabel ukuran KAP, ukuran perusahaan, dan pergantian manajemen bernilai konstan maka kemungkinan terjadinya pergantian KAP menurun sebesar 104,9 persen. Persamaan regresi 
ukuran $\operatorname{KAP}\left(X_{1}\right)$ menunjukkan koefisien bernilai negatif sebesar 0,810 yang berarti bahwa apabila perusahaan menggunakan KAP berskala besar maka kemungkinan perusahaan tersebut melakukan pergantian KAP akan menurun, dengan asumsi faktor lainnya tetap. Variabel ukuran perusahaan $\left(X_{2}\right)$ menunjukkan koefisien bernilai positif sebesar 0,596 yang menunjukkan bahwa semakin besar ukuran suatu perusahaan maka kemungkinan perusahaan tersebut melakukan pergantian KAP juga semakin tinggi, dengan asumsi faktor lainnya tetap. Variabel pergantian manajemen $\left(X_{3}\right)$ memiliki nilai koefisien positif sebesar 0,362 yang memiliki arti bahwa apabila perusahaan melakukan pergantian manajemen maka kemungkinan perusahaan tersebut melakukan pergantian KAP semakin besar, dengan asumsi faktor lainnya bernilai konstan.

Hipotesis pertama dalam penelitian ini adalah ukuran KAP berpengaruh negatif pada pergantian KAP. Hasil pengujian regresi logistik menunjukkan bahwa variabel ukuran KAP berpengaruh negatif pada pergantian KAP. Hasil ini dapat dilihat dari hasil uji hipotesis dimana nilai koefisien variabel negatif sebesar 0,810 dengan signifikasi sebesar 0,023 yang nilainya lebih kecil dari nilai signifikasi variabel yang lebih kecil dari 0,05.

Ukuran KAP merupakan besar kecilnya suatu KAP yang digunakan perusahaan dan diukur berdasarkan pendapatan, jumlah sumber daya yang dimiliki, maupun reputasi dari KAP tersebut. Hasil ini membuktikan bahwa sebagian besar perusahaan akan mencari KAP besar karena KAP besar dipercaya dapat menurunkan risiko timbulnya konflik kepentingan antara pemilik dan manajer. KAP besar memiliki kredibilitas yang tinggi di mata pemakai laporan keuangan. Expertise KAP merupakan salah satu atribut dalam servis KAP besar yang akan menentukan pergantian KAP oleh perusahaan sehingga perusahaan lebih memilih menggunakan jasa audit dari KAP besar. Selain itu, perusahaan audit yang lebih besar memiliki kualitas audit yang lebih unggul karena mereka berinvestasi lebih banyak dalam bidang audit teknologi dan pelatihan serta cenderung memiliki sumber daya yang kompeten dengan jumlah yang banyak dan didukung dengan sistem yang lebih canggih sehingga audit yang dilaksanakan hasilnya lebih akurat (Indah Sari \& Widanaputra, 2016). Hal ini menyebabkan perusahaan yang telah bekerja sama dengan KAP besar cenderung untuk tidak mengganti KAP untuk mencegah timbulnya konflik kepentingan sehingga dapat meningkatkan kepercayaan investor dan perusahaan akan tetap memperoleh dana. Hasil penelitian ini berhasil mendukung hasil penelitian dari Aprillia (2013), Satriantini et al., (2014) dan Kasharmeh (2015) yang menemukan bahwa ukuran KAP berpengaruh negatif pada pergantian KAP.

Hipotesis kedua dalam penelitian ini adalah ukuran perusahaan berpengaruh positif signifikan pada pergantian KAP. Hasil pengujian regresi logistik menunjukkan bahwa variabel ukuran perusahaan berpengaruh positif dan tidak signifikan pada pergantian KAP. Hasil ini dapat dilihat dari hasil uji hipotesis dimana koefisien variabel bernilai positif sebesar 0,596 dengan tingkat signifikasi sebesar 0,151 yang lebih besar dibandingkan dengan nilai signifikasi 0,05. Nilai signifikasi variabel ukuran perusahaan yang lebih besar dari 0,05 memiliki arti bahwa hipotesis kedua ditolak yang menyatakan bahwa ukuran perusahaan tidak berpengaruh pada pergantian KAP. 
Nilai signifikasi yang lebih besar dari taraf nyata 0,05 menandakan bahwa ukuran perusahaan tidak berpengaruh pada kemungkinan perusahaan melakukan pergantian KAP. Semakin besar ukuran perusahaan tidak menjadikan dasar untuk perusahaan melakukan pergantian KAP. Perusahaan-perusahaan besar cenderung bertahan dengan KAP yang lama dibandingkan dengan melakukan pergantian KAP yang baru. Hal ini dikarenakan sejak awal perikatan perusahaan besar cenderung sudah memilih KAP yang besar dan memiliki reputasi yang baik sehingga perusahaan besar tidak melakukan pergantian KAP. Oleh karena itu, hal ini memberikan indikasi perusahaan akan melakukan perikatan yang lama terhadap KAP yang ditunjuknya sejak awal perikatan. Hasil penelitian ini mendukung penelitian Ginting \& Hidayat (2019) dan Juliana \& Widodo (2019) yang menyatakan bahwa ukuran perusahaan tidak berpengaruh pada pergantian KAP.

Hipotesis ketiga dalam penelitian ini adalah pergantian manajemen berpengaruh positif signifikan pada pergantian KAP. Hasil pengujian regresi logistik menunjukkan bahwa variabel pergantian manajemen berpengaruh positif dan tidak signifikan pada pergantian KAP. Hasil ini dapat dilihat dari hasil uji hipotesis dimana nilai signifikasi variabel pergantian manajemen sebesar 0,325 yang lebih besar dibandingkan dengan nilai signifikasi 0,05. Nilai signifikasi variabel pergantian manajemen yang lebih besar dari 0,05 memiliki arti bahwa hipotesis ketiga ditolak yang menyatakan bahwa pergantian manajemen tidak berpengaruh pada pergantian KAP.

Tingkat signifikasi yang lebih besar dari taraf nyata 0,05 menandakan bahwa pergantian manajemen tidak berpengaruh signifikan pada kemungkinan perusahaan melakukan pergantian KAP. Satriantini et al., (2014) mengungkapkan bahwa pergantian manajemen dalam penelitian tersebut tidak terbukti menyebabkan pergantian KAP karena pergantian manajemen merupakan perubahan yang terletak di dalam dan dikendalikan oleh organisasi, yang meliputi perubahan dalam hal teknologi, visi misi perusahaan, restrukturisasi tenaga kerja, kerja sama dengan perusahaan lain atau pengadaan program baru. Keputusan untuk berganti KAP merupakan perubahan yang terjadi di luar organisasi. Oleh karena itu, dalam penelitian tersebut pergantian manajemen tidak berpengaruh pada pergantian KAP. Hasil penelitian ini mendukung penelitian dari Satriantini et al., (2014) serta Maryani \& Fahruriza (2015) yang menyatakan bahwa pergantian manajemen tidak berpengaruh pada kemungkinan pergantian KAP yang dilakukan oleh perusahaan.

Keputusan suatu perusahaan melakukan pergantian KAP akan menjadi topik yang sangat penting untuk diketahui faktor-faktor yang melatarbelakangi perusahaan melakukan pergantian KAP. Akibatnya adalah setiap pergantian akuntan publik maupun pergantian KAP yang dilakukan oleh perusahaan akan menjadi isu yang penting untuk perusahaan maupun investor. Penelitian ini membuktikan bahwa ukuran KAP berpengaruh negatif pada pergantian KAP, sedangkan variabel ukuran perusahaan dan pergantian manajemen tidak berpengaruh pada pergantian KAP yang dilakukan oleh perusahaan. 


\section{SIMPULAN}

Ukuran KAP berpengaruh negatif pada pergantian KAP. Hal ini berarti perusahaan yang telah menggunakan jasa audit dari KAP berskala besar cenderung untuk tidak melakukan pergantian KAP dibandingkan dengan perusahaan yang menggunakan jasa audit dari KAP berskala kecil. Ukuran perusahaan tidak berpengaruh pada pergantian KAP. Hal ini berarti besar kecilnya ukuran suatu perusahaan tidak mempengaruhi perusahaan untuk melakukan pergantian KAP karena perusahaan-perusahaan besar cenderung bertahan dengan KAP yang lama dibandingkan dengan melakukan pergantian KAP yang baru.

Ukuran perusahaan dan pergantian manajemen tidak berpengaruh pada pergantian KAP. Hal ini berarti besar kecilnya ukuran perusahaan dan pergantian manajemen perusahaan tidak mempengaruhi suatu perusahaan untuk melakukan pergantian KAP.

Bagi investor hendaknya lebih memperhatikan alasan perusahaan melakukan pergantian KAP karena alasan tersebut dapat menjadi salah satu prediktor kinerja perusahaan tersebut. Bagi perusahaan hendaknya mempublikasikan laporan keuangannya secara lengkap karena mempublikasikan laporan keuangan yang telah diaudit merupakan salah satu bentuk pertanggung jawaban manajemen perusahaan kepada investor. Penelitian selanjutnya diharapkan mempertimbangkan untuk menggunakan seluruh perusahaan yang terdaftar di Bursa Efek Indonesia (BEI) sebagai obyek penelitian untuk mendapatkan hasil yang lebih mampu menggambarkan fenomena pergantian KAP pada perusahaan-perusahaan yang terdaftar di BEI.

\section{REFERENSI}

A. Arens, Randal, E., \& Beasley, M. S. (2012). Auditing and Assurance Services : An integrated Approach. In Fourteenth Edition.

Ajzen, I. (1991). The Theory of Planned Behavior. Organizational Behavior and Human Decision Processes. https:// doi.org/10.1016/0749-5978(91)90020-T

Aprillia, E. (2013). Analisis Faktor-Faktor Yang Mempengaruhi Auditor Switching. Accounting Analysis Journal, 2(2), 199-207. https://doi.org/10.15294/aaj.v2i2.1577

Aroh, J. C., Odum, A. N., \& Odum, C. G. (2018). Determinants of Auditor Switch: Evidence From Quoted Companies in Nigeria. International Journal of Management Research and Business Strategy, 6(4).

Bagherpour, M., Monroe, G. S., \& Shailer, G. (2008). Auditor Switching in an Increasingly Competitive Audit Market. 1-31.

Budi, S., Rina, A., \& Oemar, A. (2015). Faktor-faktor yang Mempengaruhi Perusahaan Berpindah Kantor Akuntan Publik pada Perusahaan Manufaktur yang Terdaftar di BEI Tahun 2009-2013. Universitas Pandanaran Semarang, (2).

Chadegani, A. A., Mohamed, Z. M., \& Jari, A. (2011). The Determinant Factors of Auditor Switch Among Companies Listed on Tehran Stock Exchange. International Research Journal of Finance and Economics, (80), 158-168.

Corbella, S., Florio, C., \& Gotti, G. (2012). Mandatory Auditor Rotation , Audit Fees and Audit Quality. (April). 
Dang, C., Li, Z. (Frank), \& Yang, C. (2018). Measuring Firm Size in Empirical Corporate Finance. SSRN Electronic Journal, 86(1), 159-176. https://doi.org/10.2139/ssrn.2345506

Ginting, C. U., \& Hidayat, W. (2019). The effect of a fraudulent financial statement, firm size, profitability, and audit firm size on audit delay. International Journal of Innovation, Creativity and Change, 9(7), 323-341.

Hudaib, M., \& Cooke, T. E. (2005). The Impact of Managing Director Changes and Financial Distress on Audit Qualification and Auditor Switching. Journal of Business Finance and Accounting. https://doi.org/10.1111/j.0306686X.2005.00645.x

Indah Sari, I., \& Widanaputra, A. (2016). Reputasi Auditor Sebagai Pemoderasi Pengaruh Audit Fee Pada Auditor Switching. E-Jurnal Akuntansi, 16(1), 527556.

Juliana, \& Widodo, A. (2019). The effect of audit committee financial expertise, auditor specialists experience, and audit rotation on audit quality. International Journal of Innovation, Creativity and Change, 9(7), 355-379.

Kasharmeh, H. A. (2015). Determinants of Auditor Switching in Bahraini's Listed Companies - an Empirical Study. European Journal of Accounting, Auditing $\begin{array}{llll}\text { and Finance } & \text { 73-9earch, }\end{array}$ https://doi.org/10.1017/CBO9781107415324.004

Mahantara, A. A. G. W. (2013). Faktor-Faktor yang Memengaruhi Pergantian Kantor Akuntan Publik pada Perusahaan yang Terdaftar di Bursa Efek Indonesia. E-Jurnal Ekonomi Dan Bisnis Universitas Udayana, 724-736. Retrieved from https://ojs.unud.ac.id/index.php/EEB/article/view/6742

Maryani, N., \& Fahruriza, F. (2015). Pengaruh Opini Audit, Pergantian Manajemen, dan Reputasi Auditor Terhadap Auditor Switching (Studi Kasus pada Perusahaan Manufaktur yang Terdaftar di BEI Tahun 2009-2013) (pp. 263-269). pp. 263269. Proceedings SNEB.

Meilala, H. A. ., \& Sulistyawati, A. I. (2017). Pergantian Kantor Akuntan Publik dan Faktor-faktor yang Mempengaruhinya. Maksimum Media Akuntansi Universitas Muhammadiyah Semarang, 8(1), 33-47.

Mintz, S. (2018). Accounting in the Public Interest An Historical Perspective on Professional Ethics. The CPA Journal, 1(1), 1-20.

Nasser, A. T. A., Wahid, E. A., Nazri, S. N. F. S. ., \& Hudaib, M. (2006). AuditorClient Relationship: The Case of Audit Tenure and Auditor Switching in Malaysia. Managerial Auditing Journal, 21(7), 724-737. https://doi.org/10.1108/02686900610680512

Palmrose, Z.-V. (1986). The Effect of Nonaudit Services on the Pricing of Audit Services: Further Evidence. Journal of Accounting Research, 24(2), 405. https://doi.org/10.2307/2491144

Satriantini, P., Sinarwati, N. K., \& Sri, L. M. (2014). Pengaruh Pergantian Manajemen, Opini Audit, dan Ukuran KAP Terhadap Pergantian KAP Pada Perusahaan Real Estate dan Properti yang Terdaftar di BEI Periode 20092013. Jurnal Akuntansi SI, 2(1).

Sidhi, B. M., \& Wirakusuma, M. (2015). Pengaruh Ukuran Perusahaan, Tingkat Penjualan Perusahaan, dan Reputasi KAP pada Pergantian KAP. E-Jurnal Akuntansi Universitas Udayana, 13(3), 723-736. 
Suarjana, I. W., \& Widhiyani, N. L. S. (2015). Faktor Klien yang Memengaruhi Pergantian Kantor Akuntan Publik di Bursa Efek Indonesia. E-Jurnal Akuntansi Universitas Udayana, 10(1), 78-90.

Suparlan, \& Andayani, W. (2010). Analisis Empiris Pergantian Kantor Akuntan Publik Setelah Ada Kewajiban Rotasi Audit. Simposium Nasional Akuntansi XIII.

Susanto, Y. K. (2018). Auditor switching: management turnover, qualified opinion, audit delay, financial distress. International Journal of Business, Economics and Law, 15(5), 125-132.

Weiner, J. (2012). Auditor Size vs Audit Quality: An Analysis of Auditor Switches. 132. 